\title{
Retelling the International Paper Story
}

\author{
Douglas L. Leslie ${ }^{\dagger}$
}

\section{INTRODUCTION}

In Industrial Relations in Transition: The Paper Industry Example,' Jack Getman and Ray Marshall contend that employers should follow a highperformance, as opposed to a low-wage, strategy. They try to justify this contention by comparing the labor relations experience of International Paper (IP) with that of other paper industry firms, which have viable unions. In order to have a high-performance strategy, they argue, a firm must have a union with enough power to protect the worker. They claim that our labor laws and the courts that administer them are destroying, not promoting, unionization. They conclude that policymakers ought to change these labor laws-including, among others, the legal rule allowing firms to hire permanent replacements for striking workers.

Getman and Marshall begin with the story of IP. I will begin by retelling that story, omitting much of the detail, but retaining the gist of the facts in Getman and Marshall's account. I argue that the political agenda that permeates their article, as well as the methodology that they employ, undermines the credibility of their conclusions and the persuasiveness of their proposal for labor law reform.

\section{THE STORY RETOLD}

In the 1980's, as a result of changing economic climates in the United States and abroad, and due to technical innovations, managers of IP began a program to lower labor costs and thereby make the company more profitable. An important step in this program was to persuade the union representing the IP workers to agree to adjust wages to reflect the changed conditions and to relax restrictive union work rules that prevented new technology from being used effectively. ${ }^{2}$ IP managers sought to enlist employee support through joint manager-worker meetings and committees. But because this would lead to a

\footnotetext{
$\dagger$ Charles O. Gregory Professor, School of Law, University of Virginia.

1. Julius G. Getman \& F. Ray Marshall, Industrial Relations in Transition: The Paper Industry Example, 102 YALE L.J. 1803 (1993).

2. For a classic study which explains how unions have contributed to restrictive work rules, see W. HABER \& H. LEVINSON, LABOR RELATIONS AND PRODUCTIVITY IN THE BuILDING TRADES 164-65 (1956).
} 
reduced role for union leaders, and presumably a loss of esteem for them, the leaders persuaded workers that the company efforts were not well-intentioned.

The union's reluctance to cooperate was illustrated by an incident that signalled to managers that it would take a major effort to put IP employment on the right track. Top-level managers decided that they could begin to improve productivity and profitability by conducting a study of how the workplace was, in fact, presently organized. Employees were asked to cooperate by writing training manuals that would describe precisely the components of their jobs. While managers could have brought in outsiders to observe what employees did, a better (cheaper) approach was to ask the employees themselves. Union leaders, however, directed the employees not to write the manuals, on the ground that keeping the details of the production processes secret from managers, if the workers could do so, would make future strikes more likely to succeed.

Despite such union intransigence, IP managers made another effort to secure changes by enlisting employee cooperation, this time through collective bargaining. What managers wanted most was to eliminate work rules limiting the tasks a particular worker would do to those described in her narrow job classification. If a maintenance mechanic had no maintenance work to do, for example, these work rules prohibited assigning her temporary clean-up duties. The union rejected out of hand the "team concept" proposal, contending that it would create safety dangers. In fact, the union rejected the proposal because it might allow the plant to produce the same output with fewer workers. Fearing a union strike, IP managers prepared by contacting a firm known for its ability to secure replacements for strikers.

IP strategized that it had to modernize the work force throughout the company's North American operations. The company's goals were clear. Managers intended to emerge from a strike, if it came, with increased authority to direct the work force, reduce the number of employees and lower labor costs. After failing to accomplish these things by enlisting the support of current workers and their union, managers determined to take the steps necessary to accomplish them without the union's consent. Urged by local union leaders to reject the company's proposed bargaining agreement, IP workers struck. It was a big mistake for the workers and for their union.

Unions win strikes for a number of reasons. Sometimes they win strikes by employing secondary boycotts, acts of violence, or intimidation. They can win by getting government to exert pressure on managers. Unions can also successfully use publicity campaigns against managers of the struck company, their suppliers, and customers. But most importantly, a union can win a strike if the workers possess skills and knowledge that are specific to the firm or the industry, so that managers cannot replace them with newcomers, at least in the 
short run. ${ }^{3}$ The IP strikers lacked these specific skills and it cost them their jobs.

The paperworkers union in Getman and Marshall's case study did not succeed in enlisting effective support from government-in this case, from the town of Jay, Maine-when two antistrike replacement housing ordinances were struck down in court. ${ }^{4}$ The union also failed to succeed in its publicity campaign. (The authors do not say why the union failed, only that Jay residents won't drink Coca-Cola.) $)^{5}$ Jobs vacated by union members were filled by replacement workers. The union sought to bring pressure against the managers by extending the effect of the strike to other, unionized company locations. It did this by persuading local unions not to accept a bargaining agreement with IP until they all did. However, local union defections doomed this pooling arrangement. Union leaders decided to end the strike, announcing that union members would unconditionally return to work, but it was too late. Most strikers had been permanently replaced. Shortly thereafter, the union was decertified.

Among the IP workers, there are winners and losers. The winners include replacement workers (and their families), who but for the strike would not have found employment at IP. They were willing to work under terms rejected by union members. The losers include strikers who could not find new employment that they found as satisfying as their jobs at IP.

There continues to be animosity between strikers and replacements at IP. There always is where jobs are at stake. Whether the management ideas for improving employee productivity at IP will be successful remains to be seen. There is no data, and it may be too early to know. But even if labor productivity never improves at the Jay IP plant, IP managers still count the effort a success because of its effect companywide. Workers in other IP plants have seen what may happen if they are inflexible in the face of changed economic needs.

3. Other things being equal, the more competitive the labor market, the greater the likelihood that a firm will be able to replace striking workers. In a perfectly competitive labor market, a firm has an infinite number of workers available to it at the market wage. A strike involving only the withdrawal of labor (i.e., not involving secondary boycotts, violence, or other tactics) will not succeed unless the strikers have skills or knowledge that are specific to the firm or the industry. Thus, the extreme cases are either where strikers have no firm-specific or industry-specific skills and can be instantly replaced, or where the skills are irreplaceable. In the latter case, the firm must settle the strike or go out of business. (Note, however, that all strikers are replaceable over the long run, as the replacement of the air traffic controllers demonstrated. See Frank Swoboda, Clinton Eyes Lifting Ban on Members of PATCO, WASH. POST, Feb. 3, 1993, at A13 (striking union members replaced and barred from all govemment employment)).

4. See Getman \& Marshall, supra note 1, at 1834.

5. Id. at 1832 . 


\section{THE GetMAN AND MARShall APPROACH}

My retelling of the IP story is consistent with the account offered by Getman and Marshall. It puts a different spin on the events, however. Their article is in the tradition of an industrial relations economics that has now largely been replaced by microeconomic studies largely based on formal models and mathematical evaluation of industry-wide or national data. ${ }^{6}$ Some of the problems created by the old narrative studies of particular labor relations environments (e.g., the "New York newspaper strike," the "Kentucky mine workers negotiations") are that they make it difficult to separate the facts from the preconceptions of the reporters, and tend to generalize from sets of very limited data.

Getman and Marshall make no effort to put aside their political agenda in recounting the events at IP. ${ }^{7}$ Thus, striking workers are marked by "group cohesiveness, loyalty, creativity, discipline, intelligence, and decency." 8 Managers, by contrast, are seeking not to involve workers in finding new ways to improve plant productivity, but "to increase managerial power" and force employees to work "with less protection against arbitrary managerial authority." This flaw permeates their observations.

\section{A. The Approach}

What is the Getman and Marshall agenda? Getman and Marshall give us little information as to what a "high-performance strategy" entails. It seems to favor a few highly-skilled, highly-paid workers over many low-skilled, lowpaid workers. ${ }^{11}$ The normative argument for this strategy is not specified, ${ }^{12}$

6. See generally Gerard Debreu, The Mathematization of Economic Theory, 81 AM. ECON. REV. I (1991) (detailing the rise of mathematical methodology in economics); see, e.g., 2 ORLEY ASHENFETTER \& RICHARD LAYARD, HANDBOOK OF LABOR ECONOMICS 1039-1268 (1986) (collection of articles about unions and labor markets, each using formal modeling and mathematical analysis of data sets).

7. See Getman \& Marshall, supra note 1, at 1871-72.

8. Id. at $1877-78$.

9. Id. at 1817.

10. Id. at 1820 .

11. The IP story does not help us to understand the features marking high-performance and low-wage firms. We are given no pre-strike, post-strike wage rates, output figures, or other productivity measures. For an example of how such a study can be conducted, see Kim B. Clark, The Impact of Unionization on Productivity: A Case Study, 33 Indus. \& LAB. REL. REv. 451 (1980). Using a fully specified microeconomic model, Clark examined data from about $80 \%$ of the cement industry, compiled over many years. These data included "tons of finished cement, hours of work, plant location, annual plant capacity, and ... the age and capacity of individual kilns. The data on manhours are broken down by department, permitting the construction of variables measuring production and supervisory or nonproduction labor input. The supervisor category includes plant management, foremen and supervisors, clerical staff, and laboratory personnel. The production category includes workers in the quarry, the raw grinding and finishing departments, and the general labor group .... [I]nformation is available on the installation and "practical' capacity of individual kilns." Id. at 456 . Using this data, and information about changes in work rules as embodied in collective agreements, Clark explored the effect of unionization on employee productivity. A critic of Clark's study could look for shortcomings in the data, or careless or distorted analysis of the data. 
nor is it obvious. High-performance strategies might be preferable because they make firms more profitable and more competitive with foreign firms. But Getman and Marshall never demonstrate this claim. They make vague references to high-performance strategies in Europe and claim that comparing IP to other paper companies yields some evidence of the greater profitability of high-performance firms, but neither is adequately supported..$^{13}$ A second normative argument is that the welfare of workers is enhanced by a highperformance strategy. This seems correct for talented, trained workers who end up with high-performance jobs, but it ignores the lost employment opportunities such a strategy entails. Which is preferable, a large restaurant with a single highly paid worker running a computerized hamburger grill or the same restaurant with 12 low-paid workers manually flipping the hamburgers?

The authors address a second proposition more directly; they argue that unions are necessary to protect workers. Nevertheless, it is difficult to capture the essentials of this claim. First, note the war metaphors. A union is involved in "many battles and a variety of theaters of operation." 14 The IP strikers had no "excessive zeal for combat." 15 Using war metaphors makes the strike look like something other than an attempt by incumbent workers to maintain wage levels and restrictive work rules.

Second, Getman and Marshall make numerous references to inequality of bargaining power between labor and management without defining such inequality or showing that it exists. ${ }^{16}$ Inequality of bargaining power between managers (the power-holders) and the worker (the powerless) has been an

Clark also interviewed workers and managers. He writes, "It was apparent from [the interviews] that retrospective interviews provide only weak evidence on the more subtle effects of unionization. Changes in morale and motivation, differences in work group efficiency, and the amount of on-the-job training appear to be difficult to assess without carefully designed questionnaires administered before and after unionization and without measurement and observation of the process in question." Id. at 463.

The Getman and Marshall study does not provide the hard data (product output, labor costs, etc., before and after the strike) that would be necessary to evaluate their conclusions. Moreover, their interview reports offer less information than needed by scholars who wish to build on their work. While the authors report that they interviewed top management, they fail (with minor exceptions) to provide even a biased account of the strike and the events leading up to it from the point of view of that management. See, e.g., Getman \& Marshall, supra note 1, at 1878 n.274.

12. Getman and Marshall merely conclude that a "high-performance strategy" is worth pursuing ("This high-performance option ... is more compatible with our own country's national interest than the low-wage alternative.") They do not specify their reasons. Getman \& Marshall, supra note 1, at 1813 (citations omitted).

13. Id. at 1810-11. The authors do not show that European firms are either more profitable or more competitive than our own. The European economy is not prospering. And even if European firms are more profitable, it may be in spite of unionization, not because of it. Nor do the authors attempt to measure the productivity or profitability of IP, Otis, or Scott. Self-serving statements from workers are no substitute for hard data. Even if those statements were treated as conclusive evidence of output per worker hour, it would not support any conclusions without labor costs information.
14. Id. at 1825 .
15. Id. at 1878 .
16. See id. at $1866-69$. 
axiom of many writers seeking to justify unionization. In fact, far from being axiomatic, inequality of bargaining power is an empty slogan.

In another context, Robert Scott and I sought to puzzle through what "inequality of bargaining power" might mean. Three features seem to mark contexts where this phrase is used. First, a large company is on one end of the bargain, while an individual is on the other end. Second, the company offers a deal, but refuses to dicker over its terms. Third, but not invariably, the company has some monopoly power in its market. ${ }^{17}$

If this is what marks inequality of bargaining power, it is a trivial concept. The features are present every time a consumer makes a trip to the grocery store to buy a banana. Are all banana purchases at a Kroger store thus marked by inequality of bargaining power, demanding a cartel of banana-buyers to offset the power of Kroger's? If so, we need a lot of cartels, including, I presume, cartels of stockholders, nonboardroom managers, and so forth. ${ }^{18} \mathrm{It}$ is not clear by what measure IP's "resources" were greater than the union's. Few unions have substantial investments in bricks and mortar, nor do unions accumulate large strike funds. We could add up the personal assets of the union's members, and compare it to IP's tangible assets, but what would be the point of doing so? A firm can have a great many assets but still be in a product market that makes it extremely vulnerable to a work stoppage.

Getman and Marshall argue that to attain a high-performance strategy, a firm needs to guarantee to employees that they will not be treated arbitrarily by management, and that such guarantees are inadequate without unions. ${ }^{19}$ Neither claim is supported. Of course some managers act arbitrarily; no market is perfect. The job of managers is to direct the operations of the firm for the

17. See Robert SCOTt \& Douglas Leslie, Contract LaW AND Theory 67 (1988).

18. A few economists have thought about whether there are widespread imperfections in the market for employees that result in workers being paid less than their marginal revenue product. See Bruce E. Kaufman, Labor's Inequality of Bargaining Power: Changes Over Time and Implications for Public Policy, 10 J. LAB. RES. 285 (1989) (arguing that employer domination of labor markets is no longer as pronounced as it once was); Bruce E. Kaufman, Labor's Inequality of Bargaining Power: Myth or Reality?, 12 J. LAB. RES. 151 (1991) (arguing that Labor does suffer from unequal bargaining power); Morgan O. Reynolds, The Myth of Labor's Inequality of Bargaining Power, 12 J. LAB. RES. 167 (1991) (same). One imperfection might be the presence of substantial firm-specific or industry-specific skills. This could be labeled inequality of bargaining power in the sense that workers are paid less than they would be in a perfectly competitive market.

If this is the meaning of the term as used by Getman and Marshall, they never mention it. Moreover, there are powerful objections to the contention that strengthening unions can eliminate this kind of bargaining inequality. All markets are imperfect, and there have been no studies demonstrating that labor market imperfections are significant or that they work in favor of firms and against workers. Second, and more important, a firm with market power would offer workers wages and benefits that are important to workers-just like a monopolistic firm offers to purchasers products that appeal to the purchasers-but the offer would be at a lower level. A monopolistic firm, like a competitive firm, would offer the mix of wages, hours, and job security that workers preferred. Elsewhere, I have argued that markets may be inadequate to control management "excesses," see Douglas L. Leslie, Labor Bargaining Units, 70 VA. L. REv. 353, 371-74 (1984). Finally, the Getman and Marshall paper does not show the presence of substantial firm-specific or industry-specific skills at International Paper, and the relative ease of replacing the strikers suggests its absence.

19. See Getman \& Marshall, supra note 1, at 1807,1820 . 
benefit of its owners. Managers have an incentive, as we all do, to slack-to act in their own interests, rather that in the interest of the firm. ${ }^{20}$ It is a form of slacking when managers reward their friends and punish their enemies in the workplace. There are two constraints on this behavior: the market for managers and the product market. Managers who slack are discharged by owners and replaced by managers who do a better job. Firms that retain managers who slack have a competitive disadvantage in the product market. Neither the market for managers nor the product market works well enough to oust all managers who slack or all firms with managers who slack. What Getman and Marshall might be suggesting is that "friction costs" (i.e., the cost of conflict between labor and management) are potentially higher in a highperformance firm than in a low-wage firm due to management's need to tap the skills and enthusiasm of workers in the high-performance setting. ${ }^{21}$ This conclusion is not self-evident. One might argue, for example, that friction costs are higher in a firm with unskilled, low-wage workers, as it would seem that an unskilled lettuce picker is more likely to be mistreated by a supervisor (thus creating friction) than a skilled IBM computer assembler.

Assuming that neither the market for managers nor the product market fully eliminates management arbitrariness, the question is not whether these markets work, but how well they work compared to alternative mechanisms. Some would argue that the arbitrariness introduced by unions exceeds that of managers in nonunion firms. If this were not the case, we might expect unionized firms to outperform their nonunion competitors, over the long run driving them from the market. ${ }^{22}$ Instead, union firms are disappearing. ${ }^{23}$

20. This is how I would define "arbitrary."

21. Getman and Marshall may well be correct that the defeat of Local 14 would not have been possible without IP's use of replacement workers. It does not follow that the success of a strike should not turn on the firm's ability to secure replacement workers. Even if one accepts the premise that unionization of workers is valuable to society generally and that collective bargaining is the best method for ensuring compromise between workers and managers, there still will be strikes. Not even in the world of jointness envisioned by Getman and Marshall will friction between labor and management be eliminated, and miscalculations entirely avoided. So the question is what should determine the success of a strike for higher wages.

I know of no answer. It is difficult to argue that the success of the strike should turn on whether management's or the union's proposal is closer to the workers' just wage. The difficulties of such an argument lie in theory and implementation. For example, if one adopts the neoclassical theory of wage determination, there is no room for the labor-monopolizing union. Even if one thought that imperfections in labor markets regularly resulted in depressed wages, measuring the marginal productivity of particular workers is beyond the ability of current economic skills. Moreover, no union is required to limit its wage demand to the rate that would pertain in a competitive market, even if that rate could be learned.

22. Richard Posner makes this argument, in the neoclassical tradition, with respect to job tenure. If I were to substitute "jointness" for "job tenure," Posner's arguments might read something like this: Although some empirical support has been marshaled for [the] productivity-enhancement theory of unionization, the theory is extremely hard to accept. It is inconsistent with the fundamental assumption of economics: that people, in this case employers, are rational profit or utility maximizers. Although this assumption may not hold true in all settings, the behavior of business employers towards their employees is one setting where it probably does. If granting his employees [jointness] will increase their productivity, the rational employer will do so, for this will reduce his costs of production. Even if the whole productivity gain is paid to the 


\section{THE RECOMMENDATIONS}

By failing to support adequately either the proposition that highperformance firms are more competitive and profitable or the proposition that high-performance firms enhance worker welfare, Getman and Marshall undermine their argument for legal reform. It is clear that a change in law could revitalize unionization in the United States. Federal law could mandate unions for workers. There would be implementation problems, and the law would not be completely successful, but it would do much for unions. Getman and Marshall, of course, do not go that far. Instead, they advocate a legislative overruling of the Mackay strike-replacement case. ${ }^{24}$

Like a law mandating unionization, overruling Mackay would make unions stronger. So would legalization of secondary boycotts, or relaxation of laws against violence. But secondary boycotts and violence have more third-party effects (i.e., injuries to bystanders and companies not involved in the dispute), so overruling Mackay may be a preferred choice.

Without a strong argument as to the competitiveness or worker welfare benefits of jointness, Getman and Marshall's argument for overruling Mackay effectively rests solely on the ground that union strikes ought to be more effective. The authors write:

Our national labor law reflects an understanding of the importance of balanced bargaining power in industrial relations. The framers of that system assumed that the strike weapon would essentially equalize bargaining power between employers and employees. ... The paper industry experience supports the general assumption of the NLRA's drafters that by increasing union power and making it more nearly equal to that of management, the law encourages mutual cooperation and not economic strife. However, the paper industry experience also

employee in the form of a higher wage, the employer will be better off. He will have lower total costs than his competitors and will therefore be able to expand his output relative to theirs and increase his profits. Even if only a single employer in a competitive industry tumbled to the advantages of granting [jointness], competition would force the others to follow suit.

Richard A. Posner, Some Economics of Labor Law, 51 U. CHI. L. REV. 988, 1000-01 (1984). I am not endorsing Posner's argument, but I do suggest that a proposal that the law encourage jointness must respond to Posner's claim. A modest effort is found in Leslie, supra note 18 . In that article, I used the "collective voice" model to make some observations about how workers may be grouped for collective bargaining.

23. The effect of unions on firm productivity and profitability has been the subject of a host of articles by economists. Many of the sources are collected in John T. Addison and Barry T. Hirsch, Union Effects on Productivity, Profits, and Growth: Has the Long Run Arrived?, 7 J. LAB. ECON. 72 (1989). Productivity is devilishly hard to measure, profitability less so. Unions reduce the profitability of firms. The methodology of these articles, which to the mathematically ignorant often seems highly technical, relies on data and formal models. The articles bear no similarity to the approach of Getman and Marshall.

24. See NLRB v. Mackay Radio \& Tel. Co., 304 U.S. 333, 345-46 (1938) (holding that an employer has "the right to protect and continue his business by supplying places left vacant by strikers. And he is not bound to discharge those hired to fill the places of strikers, upon the election of the latter to resume their employment, in order to create places for them."). 
indicates that the balance of power has shifted. Employers are more able to withstand strikes and unions are less able to utilize them successfully. Yet the Board and the courts, which have uncritically accepted a neoclassical concept of the role of unions, have become more protective of employer economic pressure. Consequently, employers like International Paper may be encouraged to pursue concessions because they believe that they can crush union resistance through tough bargaining and unilateral implementation together with the threat of hiring permanent replacements in the event of a strike. Further, employers may couple the threat of replacement with the threat that the union will be decertified. ${ }^{25}$

The neoclassical model of trade unionism ${ }^{26}$ is the prevailing model of unions for economists, ${ }^{27}$ and it will take considerably more than a casual potshot to replace it. In the neoclassical model, a union is a labor supply monopolist that, when successful, increases the wages of unionized workers, reduces the number of unionized workers, lowers the wages of workers in nonunion firms, reduces the profitability of the firm, and imposes costs on consumers. On the grounds that it takes a theory to beat a theory, especially such a widely accepted model as the neoclassical model of unions, I think that the largely unspecified high-wage/high-productivity model of Getman and Marshall fails in the competitive market for models. ${ }^{28}$ If that is so, then their case for the legislative overruling of Mackay fails as well. ${ }^{29}$

Getman and Marshall also argue for the legality of union voting pools. I have no view on whether the device ought to be lawful, but I do not find the arguments marshalled in its support persuasive. The authors report that "[i]t is undisputed that the pool system did not affect which issues participating locals discussed or how they conducted their negotiations." ${ }^{\text {"30 }}$ That is not the problem. Under the pool system, a union in Des Moines will not reach a bargaining settlement until a union in Omaha also reaches a settlement. Of course, the negotiations in Des Moines do not address issues on the table in

25. Getman \& Marshall, supra note 1 , at 1866 (citations omitted).

26. The model is described in nonformal terms in DOUGLAS LESLIE, CASES AND MATERIALS ON LABOR LAW 14-31 (3d ed. 1992).

27. See, e.g., RONALD EHRENBERg \& ROBERT SMITH, MODERN LABOR ECONOMICS 366-404 (2d ed. 1985).

28. For models that compete with the neoclassical model, see LESLIE, supra note 26 , at $31-42$ (3d ed. 1992) (describing internal labor market, relational contract, and collective goods models).

29. The best normative argument for the Mackay right to replace strikers, according to the neoclassical model, is as follows: Wage rates are likely to be competitive where labor markets are competitive, but firmspecific and industry-specific skills create bilateral monopoly problems that may depress wages below market rates. Where managers can easily replace strikers, one can infer that both the market and the wage rate are competitive. The fact that IP could replace the striking employees shows that the workers lacked valuable firm-specific or industry-specific skills, and that their demands exceeded competitive market rates. For a similar treatment of Mackay, see George M. Cohen \& Michael L. Wachter, Replacing Striking Workers: The Law and Economics Approach, in PROCEEDINGS OF NEW YORK UNIVERSITY FORTY-THIRD ANNUAL NATIONAL CONFERENCE ON LABOR 109, at 117-18 (1990).

30. Getman \& Marshall, supra note 1, at 1887. 
Omaha. From the Des Moines managers' standpoint it is worse than that: they cannot bargain for an agreement because they have no control over the issues separating the parties in Omaha. ${ }^{31}$

\section{CONCLUSION}

Unions are going out of business. ${ }^{32}$ Is it the result of an inhospitable legal climate? Getman and Marshall do not undertake to assay all the reasons for the decline of unions. Nor shall I. It is likely that unions are failing for several reasons, including press coverage that has, as long as I have studied unions, emphasized the Dave Becks, Jimmy Hoffas, and Tony Boyles of the labor movement. My impression is that managers, who used to think that unionbusting was in some vague moral sense wrong, no longer think so. Reagan's notorious discharge of the air traffic controllers ${ }^{33}$ may have set this change in motion. But the more significant cause may be the rhetoric and actions of the union movement itself, with its emphasis on battle metaphors and the acquisition of "power."

The challenge for Getman and Marshall is to present an account of why, given the strengths they perceive of jointness programs and the value of the cooperation offered by unions, managers do not get the message without an exercise or holding of additional bargaining power by unions. Second, the authors need to account for why the firms and managers that do not embrace jointness are not driving their less enlightened competitors from the market. If they offer no answers to these questions, Getman and Marshall should not be writing an article calling for major legal reform, they should be presenting seminars telling managers how they can earn more money for themselves and their firms through jointness.

31. The same could not be said if the Des Moines local union instead extended the right to vote on the ratification of the Des Moines agreement to Omaha union members. If only that happened, the Des Moines managers would know what it would take for them to settle the dispute. There may be other reasons to disallow a union the right to extend ratification privileges to nonunit members (although it is common, I believe, for all local union members to vote on ratifications even though not everyone will be covered by the agreement). My point is that this is distinguishable from pooling.

32. Of course not all unions are going under, but union representation of nonagricultural employees has now dropped to the mid-teens. Proportion of Union Members Declines to Low of 15.8 Percent, Dally LAB. REP. (BNA), No. 25, at B-3 (Feb. 9, 1993). Impressionistic evidence supports reports of the death of unions. Lawyers in law firm "labor departments" used to handle union-management cases. They lament the passing of those times. Now they handle issues of discrimination, at-will employment, and ERISA, but not labor-management. It is hard to find secondary boycott and jurisdictional dispute cases in the current reporters. The unions are too weak. Law schools, among the slowest to adapt to changes in the practice, are beginning to offer "employment law" courses which, I contend, will soon push the traditional labor law course into the "specialty" category, along with Roman Law. Even some labor law professors are moving to new fields. See PAUL C. WEILER \& GARY R. ROBERTS, THE LAW AND SPORTS (forthcoming 1993).

33. See supra note 3. 